7. Reprod. Fert. (1968) 17, 579-581

\title{
OVARIAN HORMONE CONTROL OF OVUM TRANSPORT IN THE RABBIT AS INFLUENCED BY AUTONOMIC DRUGS
}

\author{
W. J. LONGLEY, * D. L. BLACK aNd G. N. GURRIE \\ Laboratory for Reproductive Physiology, Department of Veterinary and Animal Sciences, \\ University of Massachusetts, Amherst, Mass. 01002
}

(Received 30th Fuly 1968)

Passage of ova through the oviduct of the rabbit normally requires about 3 days, and is quite uniform for most mammalian species. The influence of oestrogen on the rate of ovum movement through the oviduct appears to be dose-dependent; high doses retard, while relatively low doses increase, the rate of movement (see Chang \& Harper, 1966, for a detailed discussion). Progesterone has been reported to have no effect on transport rate (Black \& Asdell, 1959; Greenwald, 1961) while other work indicates that it may block movement (Austin, 1949) or increase rate of movement (Wislocki \& Snyder, 1933; Harper, 1964). The influence of autonomic drugs on the oviduct musculature was discussed in an earlier paper (Longley, Black \& Currie, 1968).

In this experiment the influence of various autonomic drugs on ovum transport in the rabbit, when given alone or in combination with oestrogen or progesterone, was studied.

Virgin female Dutch rabbits weighing between 1.6 and $2.4 \mathrm{~kg}$ were used in all groups and each treatment group consisted of five animals. The rabbits were individually caged with unrationed water and a commercial pelleted rabbit ration available. The females were mated to male rabbits of known fertility and killed with a lethal dose of sodium pentobarbital $36 \mathrm{hr}$ post coitum $(p c)$. The oviducts were immediately frozen and removed by the technique described by Longley et al. (1968).

The following treatment groups were considered:

1. Control (no treatment)

2. Progesterone ( $1 \mathrm{mg} / \mathrm{kg}$ body weight, $\frac{1}{2}, 12$ and $24 \mathrm{hr} p c$ )

3. Oestrogen (17 $\beta$-oestradiol-17-cyclopentylpropionate, $50 \mu \mathrm{g} / \mathrm{kg}$ of body weight $\frac{1}{2}$ hr $\left.p c\right)$

4. Epinephrine hydrochloride $(750 \mu \mathrm{g} / \mathrm{kg}, 32 \mathrm{hr} p c)$

5. Phenoxybenzamine $(3 \mathrm{mg} / \mathrm{kg} 24,28$ and $32 \mathrm{hr} p c)$

6. Propanolol ( $7 \mathrm{mg} / \mathrm{kg} \mathrm{24,} \mathrm{26,} \mathrm{28,} \mathrm{20,} 32$ and $34 \mathrm{hr} p c)$

* Present address: Department of Physiology and Biophysics, Dalhousie University, Halifax, Nova Scotia, Canada. 
7. Scopolamine $(56 \mathrm{mg} / \mathrm{kg} 24,27,30$ and $33 \mathrm{hr} \mathrm{pc})$

8. Progesterone + epinephrine

9. Progesterone + phenoxybenzamine

10. Progesterone + propanolol

11. Progesterone + scopolamine

12. Oestrogen + epinephrine

13. Oestrogen + phenoxybenzamine

14. Oestrogen + propanolol

15. Oestrogen +scopolamine

The drugs were given subcutaneously in all cases. Oestrogen and progesterone were suspended in corn oil while the other drugs were given in aqueous solution or suspension. When combinations of drugs and hormones were administered the dose level for each was the same as when given singly. The drug

TABLE 1

ANALYSIS OF VARIATION OF DRUG AND HORMONE TREATMENTS

\begin{tabular}{|c|c|c|c|c|}
\hline Source of variation & $\begin{array}{l}\text { Degrees of } \\
\text { freedom }\end{array}$ & $\begin{array}{l}\text { Sum of } \\
\text { squares }\end{array}$ & $\begin{array}{l}\text { Mean } \\
\text { square }\end{array}$ & $\begin{array}{c}F \\
\text { value }\end{array}$ \\
\hline $\begin{array}{l}\text { Whole plots } \\
\text { Treatments (T) } \\
\text { Error a }\end{array}$ & $\begin{array}{l}14 \\
60\end{array}$ & $\begin{array}{l}6187 \cdot 5 \\
2939 \cdot 3\end{array}$ & $\begin{array}{r}442 \cdot 0 \\
49 \cdot 0\end{array}$ & $9 \cdot 02 *$ \\
\hline $\begin{array}{l}\text { Split plots } \\
\text { Oviducts }(\mathrm{O}) \\
\mathrm{T} \times \mathrm{O} \\
\text { Error b }\end{array}$ & $\begin{array}{r}1 \\
14 \\
60\end{array}$ & $\begin{array}{r}495 \cdot 4 \\
226 \cdot 3 \\
1688 \cdot 8\end{array}$ & $\begin{array}{r}495 \cdot 4 \\
16 \cdot 2 \\
28 \cdot 1\end{array}$ & $\begin{array}{l}17 \cdot 6^{*} \\
>1\end{array}$ \\
\hline Total & 149 & $11537 \cdot 3$ & & \\
\hline
\end{tabular}

phenoxybenzamine (Smith, Kline and French) is an alpha adrenergic-blocking agent, while propanolol (Ayerst) is a beta adrenergic-blocking agent.

Ova were located in each oviduct and the point located averaged for each tube; the results were expressed as a percentage of total tube length. The data were analysed as a split-plot design by analysis of variance and the treatment means compared by the method of Duncan (1955).

The results of analysis of variance for treatments are presented in Table 1. There was a significant difference due to oviducts; transport in the left oviduct was the same or greater than in the right. The greatest difference occurred in Group 2 where the difference was $8.3 \%$ points in favour of the left oviduct. The average difference for all oviducts was $3.6 \%$ greater for the left. The only explanation for this, other than technique, may be the difference in number of ova ovulated. On average, the left ovary ovulated $4 \cdot 15$ ova while the right ovulated 3.17 ova, as determined by the number of ovulation points on the ovaries. The recovery rate for the experiment was $103 \%$ based on the number of ova located as compared to the number of ovulation spots counted on the ovary. Because of the variation between oviducts each was considered separately. 
The results from administration of drugs and hormones are shown in Table 2. It appears that the oestrogen level used was high in consideration of the discussion by Chang \& Harper (1966). Oestrogen, when given alone or in combination with autonomic drugs, had the greatest influence on the position at which the ova were located; progesterone did not influence ova position. The alpha adrenergic-blocking agent, phenoxybenzamine, effectively inhibits movement of ova through the oviduct. It is probable that the reduced rate of movement is due to reduced muscular activity (Longley et al., 1968). Ova were located nearer the ovarian end of the tube in rabbits receiving epinephrine and progesterone. This result would be unexpected unless the beta receptors were sensitized by progesterone. The relationship between steroid hormones and autonomic drugs needs further clarification. The cholinergic-blocking agent scopolamine does not appear to have any great influence on the position of ova.

TABLE 2

POSITION OVA WERE LOCATED 36 HR post coitum BY TREATMENT

\begin{tabular}{l|c|c|c|c|c}
\hline \multicolumn{1}{c|}{ Hormone } & None & $\begin{array}{c}\text { Epi- } \\
\text { nephrine }\end{array}$ & $\begin{array}{c}\text { Phenoxy- } \\
\text { benzamine }\end{array}$ & $\begin{array}{c}\text { Propa- } \\
\text { nolol }\end{array}$ & $\begin{array}{c}\text { Scopol- } \\
\text { amine }\end{array}$ \\
\hline None & $65.5 \%$ & $62.5 \%$ & $56.3 \% *$ & $62.2 \%$ & $70.4 \%$ \\
Progesterone & $63.5 \%$ & $55.1 \% \%$ & $56.5 \% *$ & $63.6 \%$ & $59.8 \%$ \\
Oestrogen & $55.6 \% *$ & $52.5 \% *$ & $50.9 \% *$ & $49.5 \% *$ & $46.3 \% *$ \\
\hline
\end{tabular}

* Different from control $(P \leqslant 0-05)$.

In these experiments, oestrogen was the most potent inhibitor of ovum movement through the rabbit oviduct. The alpha receptors of the adrenergic nervous system are influential in ovum transport. A problem which still is not answered is why a drug like phenoxybenzamine, which reduces oviduct muscular activity, decreases rate of movement, while oestrogen, which increases muscular activity, also decreases rate of movement. It is obvious that mechanisms other than oviduct motility are important in ovum transport.

This work was supported by the National Institutes of Health Grant No. HD00745.

\section{REFERENCES}

Austin, C. R. (1949) Fertilization and the transport of gametes in the pseudopregnant rabbit. F. Endocr. 6,63 .

BlAck, D. L. \& Asdell, S. A. (1959) Mechanisms controlling entry of ova into rabbit uterus. Am. $\mathcal{F}$. Physiol. 197, 1275.

Chang, M. C. \& Harper, M. J. K. (1966) Effects of ethinyl estradiol on egg transport and development in the rabbit. Endocrinology, 78, 860 .

Duncan, D. B. (1955) Multiple range and multiple F tests. Biometrics, 2, 1.

GreENWALd, G. S. (1961) A study of the transport of ova through the rabbit oviduct. Fert. Steril. 12, 80.

HARPER, M. J. K. (1964) The effects of constant doses of oestrogen and progesterone on the transport of artificial eggs through the reproductive tract of ovariectomized rabbits. $\mathcal{F}$. Endocr. 30, 1.

Longley, W. J., BlAGK, D. L. \& CuRRIE, G. N. (1968) Oviduct circular muscle response to drugs related to the autonomic nervous system. F. Reprod. Fert. 17, 97.

Wislocki, C. B. \& SNyDER, F. F. (1933). The experimental acceleration of the rate of transport of ova through the Fallopian tube. Bull. Fohns Hopkins Hosp. 52, 379. 